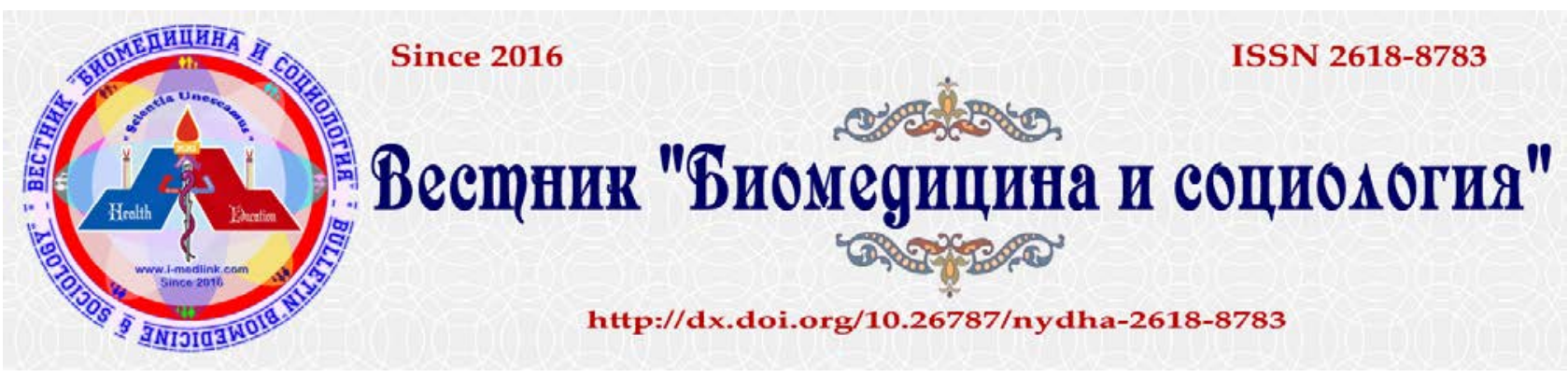

2019, том 4 [1]

http://dx.doi.org/10.26787/nydha-2618-8783-2019-4-1-28-31

\title{
MEDICAL, BIOLOGICAL AND SOCIAL ASPECTS OF AGING OF THE POPULATION OF RUSSIA AND MONGOLIA: INTERSTRANE ANALYSIS
}

Omakaeva E.U.

Kalmyk state university named after B.B. Gorodovikov, Elista, Russian Federation

\begin{abstract}
Annotation. The author of the article considers demographic aging in the Russian Federation as a process of pathological social aging of the population. Its Russian features are identified in comparison with Mongolia. Specific measures are proposed with the aim of increasing the healthy life expectancy and active longevity. The study of the stated topic is of an interdisciplinary nature, presupposing sociological, economic, medical, philosophical, linguistic and cultural factors.

The author carried out an analysis of relevant Russian and foreign publications, documents of international organizations. The materials of the article can be useful for researchers, representatives of power structures, specialists in the field of social policy, in the field of protection and medical support of the elderly.

Key words: population aging, health, demography, age structure, Russia, Kalmykia, Mongolia, the older generation, the elderly, social institutions, medical support, resource potential.
\end{abstract}

Founded in 1929, the private non-profit organization Population Reference Bureau (PRB), known to Russian-speaking readers as the Population Information Bureau, annually publishes the World Population Data Sheet, which contains information on 200 countries and includes data about the demographic situation and the health of the population in these countries (birth rates and infant mortality). According to the forecast included in this organization's annual statistical report for 2018, the world population will reach 9.9 billion by 2050, up 2.3 billion or 29 percent from an estimated 7.6 billion people now.

Population aging is one of the most important demographic processes of the modern world. Today, each new generation is smaller than the previous one. From the whole set of issues that constitute the global problem of demography, the present paper considers the problem of population aging, considered on the basis of a comparative analysis of the situation of the older generation in Russia and Mongolia.

An increase in the share of older people in the total population has recently been recorded in almost all countries, both in developed and developing countries. Both Russia and Mongolia are no exception. According to demographers, the population (especially developed countries) will continue to grow at an increasing rate.

Demographic aging and, as a result, changes in the structure of the world population, individual regions and countries can be considered one of the most significant social transformations of the 21st century, which is reflected in almost all spheres of social life. The increasing population aging process determines the demographic dynamics.

The urgency of the problem under study is related to the scale of demographic aging, which exacerbates the question of the nature and patterns of this phenomenon: is it common to all countries or has its own specific features, including regional ones. Demographic aging of the population is determined by

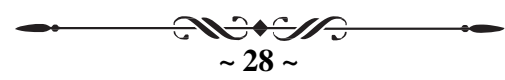

Вестник представлен в научной электронной библиотеке (НЭБ) - головном исполнителе проекта по созданию Российского индекса научного цитирования (РИНЦ) 
a number of factors, among which we can mention the birth rate, the mortality threshold, the nature of migrations, as well as their correlation. We cannot discount social and other disasters. Researchers talk about the "secondary" and "tertiary" echo of the war.

Today, an exact definition of old age, elderly, aging is an open debate. These terms have been defined variously in different societies and cross culturally. There are many theories of aging [Passuth\&Bengtson 1988; Weinert\&Timiras 2003; Rattan 2006; Ljubuncic\&Reznick 2009].

What is successful aging? [Baltes, Smith 2003; Bowling 2007]. The researchers have offered over 80 different operational definitions of successful aging but it is even unclear whether aging is a process or an outcome.

Old age as a result of the natural aging process is a certain period of life of people, coming after maturity, when there is a gradual decrease in the functional and adaptive capabilities of a person, a weakening of the activity of the human body as a whole. There is even a whole science about aging named gerontology [Kart\&Kinney 2001].

The problems of gerontology, the aging of the population in terms of its impact on the social status of older people, the equalization of relations between generations are considered in the works of Russian scientists, as well as foreign scholars. A number of works are devoted to the problems of aging and biological age, in particular, to the identification factors that accelerate and slow down aging, to the development of methods for determining biological age. The existing publications reveal features of changes in the social status of older people, which are also expressed in the position of society in relation to their economic status, negative stereotypes regarding the elderly, the phenomenon of ageism, etc.

The methodology of studying the health of aging societies is of particular importance. Today it is important to obtain objective information about the situation in modern Russian and Mongolian societies in the context of the growing aging of society, with the aim of scientific understanding of socio-demographic changes, the development of theoretical and methodological tools.

Of course, the aging trend of the population is particularly relevant for Russia, where an increase in the proportion of older persons is ahead of the growth in the population as a whole [Anderson 2002].

If the proportion of people over 60 years old is less than $8 \%$, the population is considered demographically young, and if this figure reaches $18 \%$ or more, then there is a very high level of demographic old age. It should be noted that the population of Mongolia is much younger than the population of Russia and the world population as a whole: the share of elderly people here is $7 \%$, while in the Russian Federation this figure reaches $21 \%$.

Of great interest in this regard are cross-country studies of demographic processes, in particular, the identification of cross-country correlation and differences on the example of two neighbors - Russia and Mongolia.

An important indicator in demographic terms is the standard of living of the population. In the UN list of indicators for determining living standards, the top line is occupied by such demographic criteria as fertility, mortality and life expectancy. In the 2017-2018 year, according to the Legatum Prosperity Index agency, Russia ranks 61st in the world list of 142 countries, located between Sri Lanka and Vietnam. As for the closest geographic neighbors, Russia lost to Mongolia (57th place), Belarus (58th place), while ahead of Uzbekistan (63rd place), Ukraine (64th place) and Azerbaijan (81st place). It can be seen what a breakthrough was made by Mongolia, because quite recently (in 2015!) Mongolia was only in the 90th place in the world ranking of countries in terms of living standards, noticeably lagging behind Russia (50th place). 33.7\% of the population of Mongolia are citizens under the age of 34 (this is the highest percentage of citizens of this age category in Asia).

Despite the different levels of demographic aging, both in Mongolia and Russia, problems of reforming the pension system are being discussed.

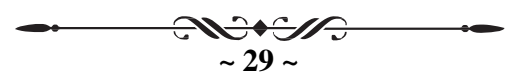


Russia and Mongolia are forced to make adjustments to their socio-economic policies, taking into account the potential consequences of demographic aging. This is indicated by pension reform, which will begin to be implemented in the countries under consideration from January 1, 2019.

Every year in Russia the number of citizens of retirement age increases. This means that situation requires modernization of the pension system.

The retirement age is considered as the legal boundary of old age. Russians have had the lowest retirement age in the world: for women - 55 years, and for men - 60 years (this age limit has been preserved in the post-Soviet space only in two more countries - the Republic of Belarus and Uzbekistan). Such a retirement plan was set back in Soviet times in 1928.

In Mongolia, for a long time, the age of access to well-deserved rest was the same as in Russia. But recently women were «equalized» in rights with men, raising their retirement age. In 2015, the Great Khural (Mongolian Parliament) revised the state policy in the field of pension reform and adopted a new bill on the retirement age. According to him, all citizens of the country, regardless of gender, retire from 60 years, but the average life expectancy of the Mongols is 70 years, which is 2.7 years lower than the Russians are. Earlier in Mongolia, there was the following situation: if a woman gave birth to four children, then she should have retired at the age of 50, with three children at 55 .

In Russia, according to data for 2016, old people numbered almost 21 million, or $14.2 \%$ of the population. Russia is a large country; the number of persons of this age varies considerably by region of residence: 6.3 million live in the Central Federal District. The least number of people of this age group is recorded in the Far Eastern Federal District (approximately 736 thousand).

About a quarter of the population of Russia are retired (as of the beginning of 2018, 46.1 million). According to preliminary forecasts, their number by 2030 will amount to a third of the country's population.

Over the past half century, the number of pensioners in Russia has more than doubled. According to the statistical yearbook "National Economy of the RSFSR-1959", the number of persons receiving state pensions at the beginning of 1959 was 11,406 thousand people. In 1970 there were already 22.5 million people.

The number of citizens of retirement age, after some stabilization in the zero years, has resumed its growth and since 2006 has been growing steadily. In 2017, there were over 42 million pensioners in Russia, of which 35 million received an old-age pension. To compare the number of old-age pensioners, let us give figures for decades starting with the collapse of the USSR: 1991 -25659, 2001 - 28813, 2011 - 32462, and 2017 - 36004.

In connection with pension reform, a new category of persons of pre-retirement age appears in Russia. President of the Russian Federation V.V. Putin proposed measures to protect people of pre-retirement age.

From 2019, the very concept of pre-retirement age is expanding: if it now means Russians, who have two years left until retirement, then during the transitional period of the pension reform (until 2028), pre-retirement age will be five years before retirement.

Generally speaking, there are three different categories of citizens older than working age: people of retirement age (from 60-65 years old), the elderly (over 70 years old) and old people (75+).

A cross-country study of population aging in Russia and Mongolia allowed us to identify both the general characteristics of this process and its features. First, it should be said about a low probability for the mass strata of the population of neighboring countries to live to a new retirement age.

Effective measures are needed to ensure a «decent old age» associated with the formation of a model of active longevity. According to the World Health Organization (WHO), the essence of the concept of

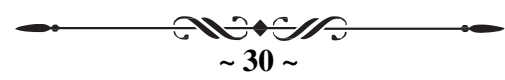


healthy aging is the creation of conditions that ensure maximum individual and functional vitality of the elderly.

\section{REFERENCES}

1. Anderson B.A. Russia faces depopulation? Dynamics of population decline // Population \& Environment. 2002. Vol. 23. № 5. C. 437-464.

2. Baltes P.B., Smith J. New frontiers in the future of aging: From successful aging of the young old to the dilemmas of the fourth age // Gerontology. 2003. Vol. 49. № 2. Pp. 123-135.

3. Bowling A. Aspirations for older age in the 21st century. What is successful aging? // International Journal of Aging and Human Development. 2007. Vol. 64. Pp. 263-297.

4. Kart C.S., \& Kinney J.M. (2001). The realities of aging: An introduction to gerontology. Needham Heights, MA: Allyn \& Bacon.

5. Ljubuncic P., \& Reznick A.Z. (2009). The evolutionary theories of aging revisited-a mini-review. Gerontology, 55(2), 205-216

6. Orimo H., Ito H., Suzuki T., Araki A., Hosoi T., \& Sawabe M. (2006). Reviewing the definition of «elderly» // Geriatrics \& gerontology international, 6(3), 149-158.

7. Passuth P.M., \& Bengtson, V.L. (1988). Sociological theories of aging: Current perspectives and future directions. Emergent theories of aging, 333-355.

8. Rattan S.I. (2006). Theories of biological aging: genes, proteins, and free radicals. Free radical research, 40(12), 1230-1238.

9. Weinert B.T., \& Timiras, P.S. (2003). Invited review: Theories of aging. Journal of applied physiology, 95(4), 1706-1716. 